\title{
Program-oriented approach to resource saving issues in construction materials industry
}

\author{
Galina Novikova ${ }^{1, *}$, Margarita Lukyanitsa ${ }^{1}$, and Larisa Chizho ${ }^{1}$ \\ ${ }^{1}$ The Department of the Economics and Projects Management in the Building, Volgograd State Technical University,Volgograd, \\ Russia
}

\begin{abstract}
The construction as a sector of the economy is one of the largest consumers of energy resources, and the building materials industry is today one of the most energy-intensive construction industry. At the enterprises of the building materials industry the different approaches and methods are used to solve resource and energy problems. Energy saving is considered not as an complex approach in the enterprise activity, but as activity for the implementation of specific energy-saving projects, which have limitations in time and in resources. The authors suggest to use a softwareoriented approach to solving the problems of resource and energy saving. For practical application of program-oriented approach we offer to use a structuring method of the decision-making, not previously used to solve problems of resource and energy saving.
\end{abstract}

\section{Introduction}

Activation of resource and energy saving is now regarded as one of the major global problems of our time due to mostly non-renewable nature of big part of the energy resources and the negative ecological impact of industrial production. Resource and energy saving is one of the most important factors providing the efficient functioning of the industry and the economy as a whole. This is achieved by implementing a complex of measures that provide the transition to the use of new environmentally friendly materials, energy saving technologies, machinery and equipment, as well as the further development of energy management systems.

Construction as a sector of the economy is one of the largest consumers of energy resources, and the building materials industry is today one of the most energyintensive construction industry and, therefore, has significant potential for use of complex resource and energy saving technologies, which focus on the development of resource and energy saving program, based on calculations and reasoned statements of managers and specialists who are familiar with the state of affairs and prospects of development in the various practice spheres of the enterprise $[1,2]$.

In this regard, the development of resource and energy programs formation methods at the enterprise has now not only theoretical but also practical importance. Creation of tool for the programs formation of resource and energy saving is a topical scientific and practical task that is aimed at improving the energy efficiency of production, reduce price cost and improve the economic efficiency of the construction company [1]. Formation of resource and energy saving programs based on programoriented approach will allow even while reducing the amount of financing to achieve high results due to the growth of labor productivity, the decrease of energy and resource capacity, the improvement of capital productivity and management efficiency [2].

Literature review. Various aspects of this problem are shown in the works of foreign and domestic scientists.

Software - oriented approach to the solution of industrial problems has been studied by following scientists: D.A. Nasimov, I.I. Doronina, V.N. Borobov, E.A. Ivanova, E.V. Gorynya, B.M. Zhukov, V.N. Leksin, B.N. Porfiryev, I.V. Osinovskaya, O.V. $\underline{\text { Lenkova, }}$ N.A. Serebryakova, Y.A. Salikov, O.Y.Kolomytseva, T.A. Pakhomova, N.V. Grishchenko $[3,4-7]$.

Problems of resource and energy saving on the scale of the national economy are explored scientists: X. Guo, Q. Zhu, L. Lv, J. Chu, J. Wu, I.J. Faber, J. Sambor, A. Bagley, Y. Niu, R.Q. Si, Z. Li, J.W. Ma, S. Dasgupta, J. Roy, Y. Bian, M. Hu, Y. Wang, H. Xu, and others [8,912].

Theoretical foundations of the energy management system, are described in the works of V. Blass, C.J. Corbett, M.A. Delmas, S. Muthulingam and others [13].

The study of various aspects of resource and energy saving in the sphere of investment and construction, the definition of the economic substance of this process have become the subject of scientific interest of authors such as A.A. Volodchenko, V.S. Lesovik, A.N. Volodchenko, E.S. Glagolev, L.H. Zagorodnjuk, Y.V. Pukharenko, K.A. Aleksandrovna, G. Balčiūnas, S.Vejelis, L. Lekūnaitè, A. Kremensas, M. Garg, A.Pundir, M.P. Devaki, B. Balakrishnan, A.S.M. Abdul Awal and etc [14,15-20].

The problems of energy saving and energy efficiency increase at the enterprise are investigated in the works of 
P.-H. Huang, S.-S. Sun, W.Liao, A. Gawlak, J. Szkutnik, Y. Fu, Z. Wei, K. Xu, L. Pang, G.J. Tsekouras, M.A. Tsaroucha, C.D. Tsirekis, A.D. Salis, E.N. Dialynas, N.D.Hatziargyriou, Y.-H. Lin, H.-H. Cho, P.C. Tsou, J.-M. Chang, H.-C. Chao and etc [21,22-25].

Analysis of the works of domestic and foreign scientists has shown that the problems, related to the formation of resource and energy saving programs as a basis for improving the economic efficiency of the enterprise, are not reflected enough, and they need the further study. It shows the need for a separate study of this problem

The purpose of the study is solution of resource problems in the building materials industry with the program-oriented approach.

The subject of the study is a set of organizational and economic relations arising in the process of resource and energy saving programs in order to improve the economic efficiency of the enterprise activity.

The objects of the study is enterprises of building materials industry, with the potential to improve energy efficiency.

Theoretical basis is fundamental and applied researches of foreign and domestic scientists and experts, these researches are dedicated to energy saving and energy efficiency increase in the enterprise.

The methodological basis of the research is the methods of system and synthesis analysis, method of analogy, comparison, expert evaluation, structural, technical-economic, logical analysis, statistical methods, the methodology of energy, strategic and innovation management.

In addition, some of the conclusions and recommendations resulting from the research are used in the practice activity of companies working in the building industry of Volgograd.

\section{Program-oriented approach to solving the problems of resource and energy saving in the enterprise}

Energy saving is now generally considered as an integrated approach to the activities of the enterprise, and also as an activity for the implementation of individual energy-saving projects that are inherent in time and resource constraints.

Energy saving is considered not as an complex approach in the enterprise activity, but as activity for the implementation of specific energy-saving projects, which have limitations in time and in resources.

For the implementation of resource and energy efficiency programs in the construction company it can be used different approaches to the formation of a complex of measures.

Theoretical part. One of the highly effective approaches, which is recommended in the practice of foreign companies management, is program-oriented approach that focuses on the achievement of clearly defined, sufficiently important purpose of enterprise development. The need to solve the problems with program-oriented method caused the fact that the problems are complex, and they need the coordination of joint efforts and resources.
Program-oriented method of planning as compared to estimate planning, has several advantages and allows to provide:

- resource concentration for solving the priority complex tasks of energy economy;

- long planning horizon, comparable with the terms of the impact and return of investment and it allows to assess the medium and long term socio-economic effects;

- systematic approach to the formation of complex of interrelated according to resources and terms of measures to achieve these purposes;

- the open procedure of the formation and implementation of target programs and their realization;

- more rational use of the allocated financial resources and ensuring the transparency of their developing.

The basis of program-oriented method is the system analysis, the essence of which is to examine the certain problem for rationale of decision-making and choice of development direction by examining its operational purposes, evaluating the effectiveness and risks associated with each alternative.

However, it is necessary to remember that the target complex program is extremely sensitive to the disturbance of any of its elements because of its complexity, connectedness of measures with terms, resources, performers

Considering this information and the experience in implementation of energy efficiency policy at the studied companies, it is proposed the use of a structuring method of the decision-making for practical use within the program-oriented approach; this method was not previously used to solve problems of resource and energy saving

This method allows to realize the structuring of purposes, objects and measures; to evaluate the economic efficiency of the enterprise; to calculate the performance order of measures. As part of this method, it is proposed to combine a targeted multistage interview with «opening» of the problem in time, that is quite feasible in the algorithmization conditions of this procedure and using computer technology.

In accordance with established methodology of program-oriented approach, the general purposes of the program should be disaggregated to the level of program measures to implement the set of program activities to ensure the achievement of program purposes. Development of the program is carried out in stages. At first, as a rule, targeted development is carried out (structuring of the original purpose, the construction of "purpose tree").

Development of the "purposes tree" allows to reveal the hierarchy of purposes in accordance with the hierarchy levels and to determine the place of program activities in achievement of specified purpose. Forming the principles of selection, evaluating the expenses and benefits associated with the implementation of another variant, the most effective options for activities are determined.

As a result, a complex of functionally expressed program activities is shown with the assessments of the relative importance of each event and quantified target specifications, complex options of objectively expressed 
purposes are developed, while purposes are formed in the form of functional or objective expressed needs, which are met in the case of achieving the main purposes.

The essence of the structuring method is in construction of "purpose tree" by multistage expert interview, using the so-called "delphic procedure" characterized by three main features: the anonymity, feedback and group response. As a result of each stage of the expert survey, the elements of one level of "purposes tree" are formed, comparative assessment is realized, the elements which do not match the accepted selection indexes, are discarded. The remaining elements are necessary to further structuring at a lower level.

This approach makes it possible to more fully explore and evaluate all the proposals of the experts. Every time experts should assess the elements of only one level "tree", that reduces the dimension of the problem and increase the validity of expert statements. This approach accelerates the process of building a "purposes tree ", because indexes of each level are evaluated according to accepted indexes of selection, and the elements, that do not correspond to them, are discarded and do not take part in the further consideration. This method is proposed for the formation of a complex of resource and energy saving measures at the enterprise JSC "Volgograd ceramic factory".

\section{The use of the decision-making structuring method for forming resource and energy saving programs at the enterprise of building sphere}

There are following stages in the formation of program: selection of problems for the including in program; decision-making of a target program development and its formation; expertise and evaluation of the target program; approval of the target program; managing the implementation of the target program and control of its realization. To form resource and energy-saving program at Implementation of resource and energy saving program will help to improve the organization and management of energy saving and economic efficiency of enterprise of building materials industry and evaluate this company, it is proposed to implement the following stages (Fig. 1).

\begin{tabular}{|c|c|}
\hline 1 stage & The definition and description of the purpose \\
\hline 2 stage & The structuring of the purpose at the task level \\
\hline 4 \\
\hline
\end{tabular}

Fig. 1. The stages of resource and energy saving program formation.

At the first stage we define the purpose - the development of an energy management system in the enterprise in order to improve the economic efficiency of the enterprise. Plan or program of actions of the resource and energy efficiency actually "translates" the energy policy of the enterprise in the language of the purposes and tasks and defines the actions required to achieve them, establishes the responsibility of specific employees, and allocates necessary for the implementation of the program (plan) of human and financial resources.

At the same time the definition of the priority purposes has the great importance.

There is purpose structuring at the task level at the second stage.

1) A group of experts is formed. The group consists of 10 people. The external energy consultant was included, who represents the energy service company. The chief engineer is in Head of the group. To compare options of achievement this purpose we use the following two groups of quantitative and qualitative indexes (Table 1).

Table 1. The elements assessment indexes of «purposes tree» at the task level.

\begin{tabular}{|c|c|c|}
\hline Index & Possible values & $\begin{array}{c}\text { Marks } \\
\text { (points) }\end{array}$ \\
\hline $\begin{array}{l}\text { Conformity of the } \\
\text { purpose }\left(h^{1}\right)\end{array}$ & $\begin{array}{l}\text { Conforms } \\
\text { Does not conform }\end{array}$ & $\begin{array}{l}1 \\
0\end{array}$ \\
\hline Purposefulness $\left(\mathrm{h}^{2}\right)$ & $\begin{array}{l}\text { Solve basic problem of } \\
\text { purpose } \\
\text { Helps to solve the main } \\
\text { purpose along with other } \\
\text { tasks } \\
\text { Helps to solve the main } \\
\text { purpose a little }\end{array}$ & $\begin{array}{c}100 \\
50 \\
10\end{array}$ \\
\hline Novelty $\left(h^{3}\right)$ & $\begin{array}{l}\text { The task is a new solution } \\
\text { The problem is an } \\
\text { improvement of the } \\
\text { existing solution }\end{array}$ & $\begin{array}{c}100 \\
50\end{array}$ \\
\hline Involvement $\left(\mathrm{h}^{4}\right)$ & $\begin{array}{l}\text { The results of the purpose } \\
\text { solution can be involved: } \\
\text { - in the scale of the sphere; } \\
\text { - in the scale of the } \\
\text { enterprise; } \\
\text { - in the certain subdivision } \\
\text { of the enterprise }\end{array}$ & $\begin{array}{c}100 \\
50 \\
10\end{array}$ \\
\hline Perspectives $\left(h^{5}\right)$ & $\begin{array}{l}\text { The results of the task } \\
\text { realization will be the basis } \\
\text { for the solution of new } \\
\text { problems } \\
\text { The results are only } \\
\text { meaningful to solve this } \\
\text { problem }\end{array}$ & 100 \\
\hline
\end{tabular}

2) Next, the coefficient of experts' competence is calculated. It can be defined as the arithmetic mean value of self-assessment of the expert group. In this case, the level of group competence is 0.96 , so it is a reliability of expertise is over $90 \%$.

3) A common list of tasks is formed, which is presented by all the experts. The generalized expert evaluation of the index is calculated.

4) The expert evaluation of each indexes of the feasibility of the tasks $h^{1}$ and $h^{2}$ is received. If most experts believe that any problem contributes a little to solve the purpose, it will be excluded from further consideration. 
5) The coefficients values of novelty $\left(\mathrm{h}^{3}\right)$, involvement $\left(\mathrm{h}^{4}\right)$, perspectives $\left(\mathrm{h}^{5}\right)$ are arranged in decrease order of their importance to determine whether the expert approach is the same to the parameters evaluation.

6) Each expert assesses the task with the use of indexes of novelty $\left(h^{3}\right)$, involvement $\left(h^{4}\right)$, perspectives $\left(h^{5}\right)$, while these indexes $h^{3}, h^{4}$ can have values 100, 50, 10 , and the index $\mathrm{h}^{5}$ have the value 100,50 .

At the third stage, the structuring of tasks is implemented at the level of events. At this stage the elements of the third-level "purpose tree" are defined, i.e. directly supposed events. It is possible to change the composition of the expert group. It includes professionals primarily of those spheres that match selected events for further consideration.

The results of the experts' survey of purposefulness $\left(\mathrm{h}^{2}\right)$ are presented in the Table 2.

Table 2. The experts' assessment of purposefulness of supposed events.

\begin{tabular}{|l|c|c|c|}
\hline \multicolumn{1}{|c|}{ Events } & \multicolumn{3}{|c|}{ Tasks } \\
\cline { 2 - 4 } & $\mathbf{1}$ & $\mathbf{2}$ & $\mathbf{3}$ \\
\hline $\begin{array}{l}\text { 1. The introduction of variable frequency } \\
\text { drives of electric engine }\end{array}$ & 100 & 80 & 70 \\
\hline $\begin{array}{l}\text { 2. Strategy of organizational changes of } \\
\text { energy policy in the enterprise }\end{array}$ & 20 & 70 & 100 \\
\hline $\begin{array}{l}\text { 3. The learning of new methods of } \\
\text { financing programs of resource and energy } \\
\text { saving }\end{array}$ & 20 & 80 & 90 \\
\hline $\begin{array}{l}\text { 4. Organization of in-house training in the } \\
\text { sphere of energy saving }\end{array}$ & 60 & 100 & 90 \\
\hline 5. Dispatching of heat supply systems & 90 & 18 & 18 \\
\hline $\begin{array}{l}\text { 6. Analysis and evaluation of the } \\
\text { efficiency functioning of the energy } \\
\text { management system }\end{array}$ & 40 & 100 & 90 \\
\hline $\begin{array}{l}\text { 7. Creation of an information system } \\
\text { (database) of the regulatory, technical and } \\
\text { regulatory documentation in the sphere of } \\
\text { energy efficiency }\end{array}$ & 70 & 80 & 90 \\
\hline $\begin{array}{l}\text { 8. Defining and updating of the policy in } \\
\text { the sphere of energy management }\end{array}$ & 30 & 100 & 90 \\
\hline $\begin{array}{l}\text { 9. Installation of meters, the introduction } \\
\text { of the automated monitoring and the } \\
\text { accounting systems of energy resources }\end{array}$ & 80 & 20 & 20 \\
\hline
\end{tabular}

The relative indexes of importance are calculated. The results of calculation of the relative importance factors are presented in the Table 3 .

Table 3. The table of coefficients of relative importance.

\begin{tabular}{|c|c|c|c|c|}
\hline \multirow{2}{*}{$\begin{array}{c}\text { 3d level of } \\
\text { «purposes tree» } \\
\text { (events) }\end{array}$} & \multicolumn{3}{|c|}{$\begin{array}{c}2 \mathrm{~d} \text { level of «purposes } \\
\text { tree» }\end{array}$} & \multirow{2}{*}{$\begin{array}{l}\text { The value of } \\
\text { each event } \\
\text { for purpose } \\
\text { realization }\end{array}$} \\
\hline & $\begin{array}{c}\text { Task } \\
1\end{array}$ & $\begin{array}{c}\text { Task } \\
2\end{array}$ & $\begin{array}{c}\text { Task } \\
3\end{array}$ & \\
\hline 1 & 0.25 & 0.13 & 0.11 & 0.15 \\
\hline 2 & 0.07 & 0.09 & 0.13 & 0.09 \\
\hline 3 & 0.08 & 0.11 & 0.14 & 0.10 \\
\hline 4 & 0.11 & 0.16 & 0.12 & 0.14 \\
\hline 5 & 0.12 & 0.01 & 0.01 & 0.05 \\
\hline 6 & 0.08 & 0.15 & 0.14 & 0.12 \\
\hline 7 & 0.07 & 0.08 & 0.06 & 0.07 \\
\hline 8 & 0.10 & 0.24 & 0.27 & 0.21 \\
\hline 9 & 0.12 & 0.03 & 0.02 & 0.07 \\
\hline
\end{tabular}

On the basis of the assessments "purposes tree" is built, which will determine the position of program activities to achieve a certain purpose - the development of an energy management system at enterprise of building materials industry (Figure 2).

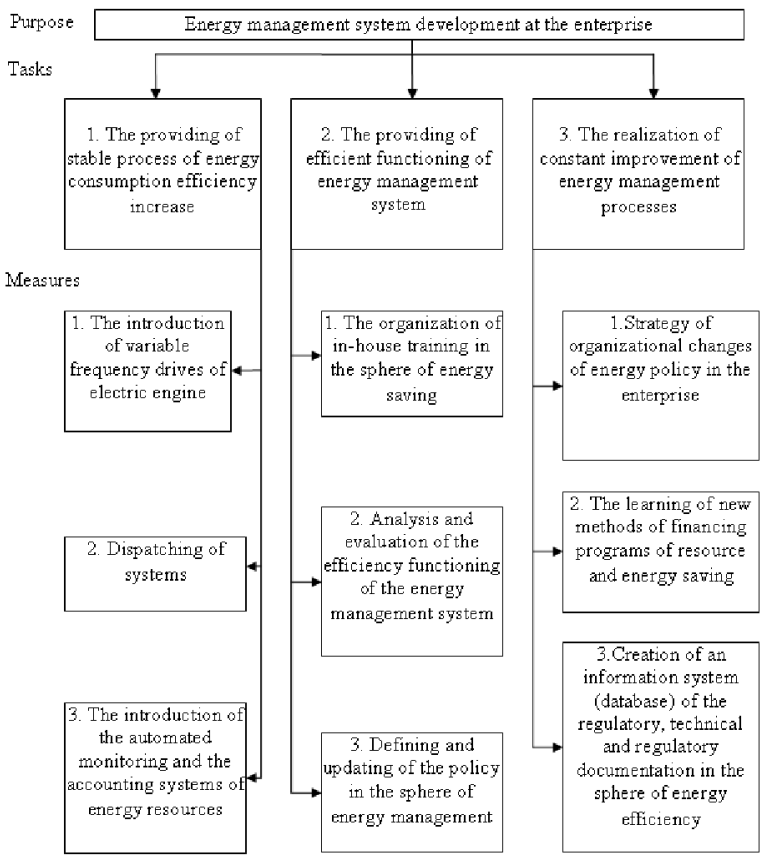

Fig. 2. «Purposes tree» of the energy management development of JSC «Volgograd ceramic factory».

At the fourth stage all the priority ways of enterprise of building materials industry activity are studied in the sphere of resource and energy saving. The measures, implementation of which will require significant financial resources, are defined.

Funding for measures of energy saving and energy efficiency increase will be carried out due to: equity of enterprise of building materials industry, the funds received as a result of reduced consumption of energy resources while the activities realization of energy saving and energy efficiency increase, and other sources.

Also periodic reports of the program activities implementation and the use efficiency of funds are considered. The evaluation provide a proposal to reallocate or change the volume of funds allocated for the implementation of the program activities.

Evaluation of the resource and energy saving program realization at the enterprise of building materials industry is presented in Table 4.

Suggested volumes of investment for the whole period of the program realization will be $t 37,708.45$ thousand rub. Economic efficiency of the implementation of the program for the period 2017-2019 will be $45,450.66$ thousand rub. The average payback period is 2.3 years.

As a result, we can conclude that these activities have a relatively high economic efficiency, their implementation is a priority for the company. 
Table 4. The evaluation of economic eficiency of resource and energy saving program realization at the enterprise.

\begin{tabular}{|c|c|c|c|c|c|}
\hline \multirow{3}{*}{ Measures } & \multicolumn{3}{|c|}{$\begin{array}{l}\text { The volume of reduction } \\
\text { of annual consumption }\end{array}$} & \multirow{3}{*}{ 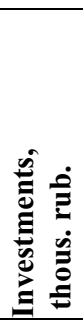 } & \multirow{3}{*}{ 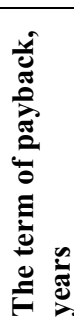 } \\
\hline & \multirow{2}{*}{$\begin{array}{l}\text { The } \\
\text { quantitati } \\
\text { ve value }\end{array}$} & \multicolumn{2}{|c|}{$\begin{array}{l}\text { The price } \\
\text { value }\end{array}$} & & \\
\hline & & $\begin{array}{l}\text { Thous } \\
\text { rub. }\end{array}$ & $\%$ & & \\
\hline $\begin{array}{l}\text { 1. The providing } \\
\text { of equipment } \\
\text { with devices of } \\
\text { variable } \\
\text { frequency drives } \\
\text { thous. } \mathrm{kW} \text {.hours }\end{array}$ & 804.0 & $\begin{array}{l}2 \\
580.8\end{array}$ & 12.3 & $\begin{array}{l}11 \\
355 . \\
5\end{array}$ & 4.4 \\
\hline $\begin{array}{l}2 . \\
\text { installation of } \\
\text { metering devices, } \\
\text { implementation } \\
\text { of the automated } \\
\text { system for } \\
\text { control and } \\
\text { accounting of } \\
\text { energy resources }\end{array}$ & - & - & - & $\begin{array}{l}181 \\
95.4\end{array}$ & 1.2 \\
\hline $\begin{array}{l}\text { - natural gas } \\
\text { savings, thous. } \\
\text { meters }^{3}\end{array}$ & 3276.1 & $\begin{array}{l}1222 \\
9.1\end{array}$ & 57.1 & - & - \\
\hline $\begin{array}{l}\text { - drinking and } \\
\text { technical water } \\
\text { saving, thous. } \\
\text { meters }^{3}\end{array}$ & 21.74 & 739.6 & 3.4 & - & - \\
\hline $\begin{array}{lr}\text { - electric energy } \\
\text { saving, } \\
\mathrm{kW} \text { 'hours }\end{array}$ & 1219.8 & $\begin{array}{l}3 \\
915.6\end{array}$ & 18.2 & - & - \\
\hline $\begin{array}{l}\text { 3. Dispatching } \\
\text { of heat supply } \\
\text { systems }\end{array}$ & - & - & - & $\begin{array}{l}643 \\
2.45\end{array}$ & 3.3 \\
\hline $\begin{array}{l}\text { - heat resources } \\
\text { saving, Gcal }\end{array}$ & 2357.5 & $\begin{array}{l}1 \\
933.2\end{array}$ & 9.0 & - & - \\
\hline $\begin{array}{l}\text { 4. The creation } \\
\text { of information } \\
\text { system }\end{array}$ & - & - & - & $\begin{array}{l}172 \\
5.1\end{array}$ & - \\
\hline In total & - & $\begin{array}{l}2139 \\
8.3\end{array}$ & 100 & $\begin{array}{l}377 \\
08.5\end{array}$ & 2.3 \\
\hline
\end{tabular}

\section{Conclusion}

Implementation of resource and energy saving program will help to improve the organization and management of energy saving and economic efficiency of enterprise of building materials industry.

Solving the problems of energy saving and increase enterprise efficiency is advantageously carried out on the basis of program-oriented method by implementing the set of measures associated by the purposes, tasks, resources, and terms of realization. As a result of the introduction of program-oriented method, the organizational and financial-economic energy saving mechanisms are realized. The projects are implemented to introduce energy-saving equipment and technologies, to produce energy-efficient equipment and materials, to increase energy efficiency of the company, to reduce emissions of harmful substances and the consumption of non-renewable energy resources.

\section{References}

1. O.A. Baulina, V.V. Klyushin, and A.E. Shchukin, Globalization and its socio-economic consequences, 2016, I, 127-134 (2016)

2. G. Novikova, A. Chub, J. Gushina, Globalization and its socio-economic consequences, 2016, IV, 1547-1554 (2016)

3. D.A. Nasimov, Indian Journal of Science and Technology, 9, 16, 90049 (2016)

4. I.I. Doronina, V.N. Borobov, E.A. Ivanova, E.V. Gorynya, B.M. Zhukov, Int. Journal of Econ. and Fin. Issues, 6, 1S, 295-299 (2016)

5. V.N. Leksin, B.N. Porfiryev, Studies on Russian Econ. Develop., 26, 6, 555-560 (2015)

6. I.V. Osinovskaya, O.V. Lenkova, Int. Business Man., 9, 2, 164-168 (2015)

7. N.A. Serebryakova, Y.A. Salikov, O.Y. Kolomytseva, T.A. Pakhomova, N.V. Grishchenko, Asian Soc. Science, 11, 20, 193-205 (2015)

8. X. Guo, Q. Zhu, L. Lv, J. Chu, J. Wu, Jour. of Clean. Prod., 140, 1313-1321 (2017)

9. I.J. Faber, J. Sambor, A. Bagley, IIE Annual Conference and Expo 2014, 3069-3076 (2014)

10. Y. Niu, R.Q. Si, Z. Li, J.W. Ma, Adv. Mater. Research, 1030-1032, 2573-2577 (2014)

11. S. Dasgupta, J. Roy, Energy Efficiency, 1-19 (2016)

12. Y. Bian, M. Hu, Y. Wang, H. Xu, Renew, Sust. Energy Reviews, 55, 990-998 (2016)

13. V. Blass, C.J. Corbett, M.A. Delmas, S. Muthulingam, Energy, 65, 560-571 (2014)

14. A.A. Volodchenko, V.S. Lesovik, A.N. Volodchenko, E.S. Glagolev, L.H. Zagorodnjuk, Y.V. Pukharenko, Int. Jour. of Pharm. and Techn., 8, 3, 18856-18867 (2016)

15. A.A. Volodchenko, V.S. Lesovik, A.N. Volodchenko, L.H. Zagorodnjuk, Int. Jour. of Appl. Engin. Research, 10, 24, 45142-45149 (2015)

16. A.A. Volodchenko, V.S. Lesovik, L.H. Zagorodnjuk, A.N. Volodchenko, K.A. Aleksandrovna, Research Jour. of Appl. Sciences, 10, 12, 931-936 (2016)

17. G. Balčiūnas, S. Vèjelis, L. Lekūnaitè, A. Kremensas, Environmental Engin. and Manag. Jour., 15, 3, 699-705 (2016)

18. M. Garg, A. Pundir, Eur. Jour. of Environmental and Civil Engin, 1-17 (2016)

19. M.P. Devaki, Key Engin. Materials, 678, 135-143 (2016)

20. B. Balakrishnan, A.S.M. Abdul Awal, Key Engin. Materials, 678, 99-108 (2016)

21. P.-H. Huang, S.-S. Sun, W.Liao, IEEE Transact. on Mob. Comp., 16, 1, 143-157 (2017) 
22. A. Gawlak, J. Szkutnik, Proceedings of the 8th Int. Scien. Symposium on Electric. Pow. Engin., 208-210 (2015)

23. Y. Fu, Z. Wei, K. Xu, L. Pang, 44th Int. Conf. on Large High Voltage Electric Syst., 10 (2012)

24. G.J. Tsekouras, M.A. Tsaroucha, C.D. Tsirekis, A.D. Salis, E.N. Dialynas, N.D. Hatziargyriou, Int.
Jour. of Electric. Pow. and Energy Syst., 33(6), 1220-1228 (2011)

25. Y.-H. Lin, H.-H. Cho, P.-C. Tsou, J.-M. Chang, H.C. Chao, Int. Conf. on Advanc. Communication Technology, ICACT, 1409-1413 (2011) 